\title{
The Emerging Role(s) for Kisspeptin in Metabolism in Mammals
}

\author{
Andrew Wolfe ${ }^{1 *}$ and Mehboob A. Hussain ${ }^{2}$ \\ ${ }^{1}$ Department of Pediatrics, Johns Hopkins University, Baltimore, MD, United States, ${ }^{2}$ Department of Internal Medicine \\ Metabolism, Endocrinology and Diabetes, University of Michigan, Ann Arbor, United States
}

Kisspeptin was initially identified as a metastasis suppressor. Shortly after the initial discovery, a key physiologic role for kisspeptin emerged in the regulation of fertility, with kisspeptin acting as a neurotransmitter via the kisspeptin receptor, its cognate receptor, to regulate hypothalamic $\mathrm{GnRH}$ neurons, thereby affecting pituitary-gonadal function. Recent work has demonstrated a more expansive role for kisspeptin signaling in a variety of organ systems. Kisspeptin has been revealed as a significant player in regulating glucose homeostasis, feeding behavior, body composition as well as cardiac function. The direct impact of kisspeptin on peripheral metabolic tissues has only recently been recognized. Here, we review the emerging endocrine role of kisspeptin in regulating metabolic function. Controversies and current limitations in the field as well as areas of future studies toward kisspeptin's diverse array of functions will be highlighted.

\section{OPEN ACCESS \\ Edited by:}

William Henry Colledge, University of Cambridge,

United Kingdom

Reviewed by:

Carol F. Elias,

University of Michigan,

United States

Takeshi Onuma,

Osaka University, Japan

${ }^{*}$ Correspondence:

Andrew Wolfe

awolfe3@jhmi.edu

Specialty section: This article was submitted

to Neuroendocrine Science,

a section of the journal

Frontiers in Endocrinology

Received: 15 January 2018

Accepted: 05 April 2018

Published: 24 April 2018

Citation:

Wolfe $A$ and Hussain MA (2018) The Emerging Role(s) for Kisspeptin in Metabolism in Mammals.

Front. Endocrinol. 9:184. doi: 10.3389/fendo.2018.00184
Keywords: kisspeptin, obesity, pancreas, liver, adipocytes, mouse models

\section{INTRODUCTION}

\section{Historical Summary of Kisspeptin}

The kisspeptin (Kiss1) gene was first identified in a screen of human genes that reduced the metastatic potential of human melanoma cells (1). Since its discovery, kisspeptin has been a focus of study for a series of different fields including cancer biology, reproductive neuroendocrinology, reproductive biology, and, most recently, metabolism. While the kisspeptin gene and its activation of the kisspeptin receptor (KISS1R) were initially characterized by cancer biologists $(1,2)$, in 2003 , the study of kisspeptin accelerated following the demonstration by two groups of its essential role in regulating reproductive function $(3,4)$. This can be dramatically illustrated by performing a literature search for articles on kisspeptin from the years between 1996 and 2002 (18 articles) and the subsequent 7 years, 2003-2009 (458 articles), after the seminal studies from Seminara and de Roux. The studies from this latter period define a critical role for kisspeptin signaling in the regulation of GnRH neurons, demonstrating kisspeptin involvement with puberty $(3,4)$, mediating gonadal steroid hormone negative $(5,6)$ and positive $(7,8)$ feedback and serving as an afferent pathway for metabolic control of the reproductive hormone axis (9-11). Interest in kisspeptin has further accelerated in the past 7 years (1,540 articles) as novel peripheral roles for kisspeptin have been identified in both reproductive, metabolic, and developmental processes (12-14). The aim of this review is to provide a summary of studies describing a role for kisspeptin in the peripheral regulation of metabolism.

\section{Kisspeptin and the KISS1R}

The kisspeptin gene, located on chromosome 1 in human, was originally reported to encode a 145 amino acid preprotein (15), though recent updates to the human genome sequence include a one-bp change resulting in an earlier stop codon and indicating that the human protein product is likely 
138 amino acids. The preprotein can be further processed to the biologically active 54 amino acid C-terminally amidated peptide (Kp54, metastin) that was demonstrated to activate the KISS1R previously referred to as the orphan receptor $\operatorname{GPR} 54(2,16)$. In mouse, the Kiss 1 gene, as in human, is located on chromosome 1 , and in rat, the gene is located on chromosome 13. However, for the rat and mouse genes, regulation is complicated by the expression of multiple splice variants, although, in both, the protein precursor is also processed to Kp54. For example, the rodent Kiss1 gene (mouse gene shown in Figure 1) consists of a number of splice variants that produce the same protein product $(17,18)$, suggesting that key differences in cell-specific regulation may be mediated by alternative promoter elements. This has been borne out in studies which have defined cyclic AMP response element binding protein (CREB) (19) and estrogen receptor (17) regulation of the mouse Kiss 1 gene (Figure $\mathbf{1}$ ).

The Kiss 1 gene is expressed in a variety of tissues besides the brain (hypothalamus, amygdala) (20-23), including the liver $(13,24)$, testis $(24-26)$, ovary $(27,28)$, fetal adrenal $(12)$, heart (29) fat $(24,30,31)$, and placenta (32). This provides a number of possibilities for sources of circulating kisspeptin, with strong experimental evidence suggesting that the liver and placenta can contribute to biologically significant levels in the circulation $(13,32)$.

The KISS1R gene (Kiss1r, also called Gpr54, Axor12, and hOT7T175) is a member of the G-protein-coupled receptor family and is located on chromosome 19 in human and chromosome 10 in mouse. It consists of five exons and encodes a 398 amino acid protein in humans and a 395 amino acid protein in the mouse (33).

The Kiss1R has significant homology in the transmembrane regions with the galanin receptors, yet has little affinity for galanin (34). Kiss $1 R$ was demonstrated to signal through a $G_{q / 11}$-mediated pathway to increase intracellular $\mathrm{Ca}^{2+}(35,36)$ and activate the extracellular signal-regulated kinase (ERK)-signaling pathway, stimulating GnRH secretion. Recently, in the GnRH neuron, KISS1R was also demonstrated to signal via a $\mathrm{G}_{\mathrm{q} / 11}$-independent but $\beta$-arrestin-dependent pathway leading to the activation of $\operatorname{ERK}(37,38)$.

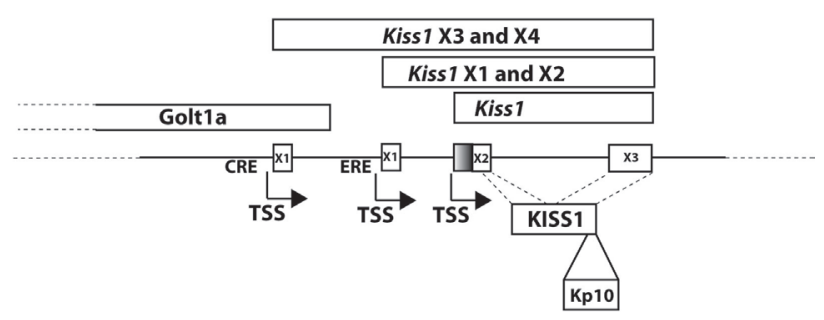

FIGURE 1 | Mouse Kiss1 gene. Transcript variants of mouse Kiss1 are expressed from two different first exons, X3 (XM_006529681) and X4 (XM_006529682), that are regulated by cyclic AMP response element binding protein at a CRE (19). The transcriptional start site for Kiss 1 X3 and X4 is located in an exon of the Golt1a gene. Kiss1X1(XM_006529679) and X2 (XM_006529680) are regulated by ESR1 at an ERE (17). Kiss1 is a transcript including just the second and third exons (NM_178260.3). X1 and $\mathrm{X} 3$ include a larger second exon (including the shaded region) and X2 and X4 include a smaller second exon. All variants produce the KISS1 protein. KP-10 is the active region of all bioactive KISS1 peptides.
Besides the hypothalamus $(39,40)$, Kiss $1 r$ has been reported to be expressed in peripheral tissues including the pituitary, adipocyte, heart, spinal cord, gonads, and pancreas (13, 16, 29-31, 41-43). These findings suggest that a range of physiological systems may be impacted by kisspeptin.

Though not activated by galanin, the Kiss1R has been demonstrated to be activated by ligands other than the kisspeptins. RFamide-related peptide-3 (RFRP-3) and its receptor, neuropeptide FF receptor 1 (NPFFR1), are the mammalian orthologs of avian gonadotrope inhibitory hormone $(\mathrm{GnIH})$ and its receptor GnIHR. RF9 is an antagonist to the GnIHR (44) that directly activates GnRH neuron firing (45) and LH secretion in a KISS1Rdependent manner (46). While kisspeptin independent activation of the KISS1R is documented, high levels of kisspeptin can also exert effects independent of the KISS1R (13) though the mechanism of action for these effects is not yet established. These data likely provide a biological rationale for the more severe reproductive phenotype observed in the Kiss $1 R$ KO mouse than in the Kiss $1 \mathrm{KO}$ mouse (47).

\section{Kisspeptin Neurons Mediate Central Regulation of Reproduction by Peripheral Metabolic Signals}

Since the initial observations describing an essential role for kisspeptin signaling in puberty $(3,4)$, it has emerged that kisspeptin neurons are also relays of steroid feedback regulation to $\mathrm{GnRH}$ neurons $(5,6,21,22,39,48,49)$ and are important components of the circuitry controlling GnRH pulse generation (50-54).

Kisspeptin neurons in the brain have also been proposed to integrate signals relaying peripheral metabolic status to the reproductive hormone axis, specifically to the $\mathrm{GnRH}$ neurons [reviewed in Ref. $(9,55,56)$ ]. There is evidence for changes in central kisspeptin expression both in response to food restriction (negative energy balance) or in genetic or diet-induced models of obesity (positive energy balance). However, to date, reports on the modulation of kisspeptin expression by caloric surfeit and obesity vary and are at times conflicting such that no firm consensus exists on the topic.

In studies on calorically restricted models, most, but not all, investigators report a reduction in Kiss 1 expression in both hypothalamic kisspeptin neuron populations. Long-term dietrestricted ewes were shown to express reduced Kiss 1 mRNA in both the ARC and POA when compared with normal weight ewes (57). And in fasted male mice, reduced hypothalamic Kiss 1 mRNA levels relative to fed controls were reported (58). In rats, one group reported $72 \mathrm{~h}$ of fasting caused a significant reduction in hypothalamic Kiss 1 expression in both males and females (59). However, another group observed no change in ARC Kiss1 expression in response to a 48-h fast and a reduction in AVPV Kiss 1 mRNA only in ovariectomized/estrogen-replaced female rats (60). Clearly, more studies will be required to address the role of hypothalamic kisspeptin in mediating the suppression of the reproductive axis in states of negative energy balance.

In diet-induced obese female mice, Kiss 1 expression in both the AVPV and ARC decreases relative to normal chow-fed controls (61), perhaps contributing to a reduced reproductive function. And in a genetic model of obesity, the leptin-deficient 
Ob/Ob mouse, ARC Kiss1 mRNA levels are reduced (49, 61, 62) or unchanged (58) as compared to control mice. In the study by Smith et al., leptin treatment of $\mathrm{Ob} / \mathrm{Ob}$ mice increased Kiss 1 expression, but this represented only a partial rescue of a reduced Kiss 1 expression reported for the Ob/Ob mouse $(21,22,49)$. Leptin has long been known to play a permissive role in reproductive function (63) and signaling via the kisspeptin neurons, which may contribute to the functional regulation of fertility by leptin.

The gut-derived hormone ghrelin could also impact the reproductive axis via kisspeptin neuronal afferents, though here again, the evidence is not clear. Some investigators have suggested that only the AVPV KISS1 neurons are regulated by ghrelin (64), and others have also identified the regulation of ARC KISS1 neurons by ghrelin, interestingly with a strong interacting effect by E2 (65). Kisspeptin neurons have been shown to express the ghrelin receptor [GHSR (65)], though they are not thought to express the leptin receptor $(62,66)$, suggesting leptin-sensitive afferent neuronal regulation of kisspeptin and/or GnRH neurons $(62,66)$. ARC kisspeptin neurons send projections to the kisspeptin neurons in the AVPV $(67,68)$, suggesting that for some processes, a two kisspeptin neuron circuit could be required. Therefore, the relative role that ARC or AVPV kisspeptin neurons play in mediating metabolic signals is not clear $(60,61,64,69,70)$.

\section{The Kiss1R Knockout Mouse Exhibits Metabolic Dysfunction and Suggests a Key Role for Kisspeptin Signaling in Regulating Metabolism}

Evidence for a broader role for kisspeptin signaling in the regulation of metabolism comes from detailed analysis of the KISS1R knockout mouse (Kiss1r KO) (71). These studies reported striking differences in body weight and glucose metabolism in female mice, but also differences in body composition and increased circulating leptin in both sexes. Because of the well-established obesity associated with a reduced estrogen signaling (72-74), Tolson et al. ovariectomized the female mice to assess those effects occurring independently of reduced estrogen. They found that a small, but significant, component of the obesity observed in female mice is due to loss of kisspeptin signaling and is not secondary to the reduction in estrogen levels, resulting from hypothalamic hypogonadism (71). However, Kiss1r KO males, because they exhibited no KISS1R-mediated weight difference, were not as carefully studied, despite having an increased adiposity and circulating leptin compared to controls. In addition, not reported in either sex was any evaluation of gluconeogenic capacity or whether there were differences in lipid metabolism despite an observed reduction in nocturnal respiratory exchange ratio (RER) in female $\mathrm{KO}$ mice compared to controls as assessed by indirect calorimetry. A reduced RER is suggestive of an increased use of lipids for energy metabolism (75). In follow-up studies in female mice, the Kauffman laboratory demonstrated that the changes in body composition, leptin levels, and RER were present in 6-week-old female $\mathrm{KO}$ mice, which preceded the increased body weight phenotype (76). The developmental progression of the phenotype observed in the male KO mice (increased adiposity, leptin levels, and reduced RER) remains still to be performed. The studies by the Kauffman laboratory have spurred a number of investigators to try to assess the tissue-specific mechanisms by which kisspeptin may regulate glucose and lipid metabolism, food intake, and body weight.

One possibility is that the body weight phenotype in Kiss1r $\mathrm{KO}$ mice is in part the result of an altered hypothalamic control of food intake or energy expenditure. Kisspeptin treatment alters both neuropeptide Y (NPY) and pro-opiomelanocortin (POMC) neuronal activity in mice (77). In sheep, kisspeptin treatment increases Npy gene expression and decreases Pomc expression (57). Using optogenetic technology, ARC kisspeptin neurons were activated in mice and demonstrated glutamine, secreted from kisspeptin neurons regulation of both POMC and agouti-related peptide neurons. Interestingly, this resulted in the excitation of POMC neurons, via Gq/G11 coupled glutamate receptor and the inhibition of AgRP neurons, via a $\mathrm{G}_{\mathrm{i}} / \mathrm{G}_{\mathrm{o}}$ coupled glutamate receptor (78).

To address whether the underlying cause of the obesity in female Kiss1r KO mice was at the level of the hypothalamus, De Bond et al. used quantitative PCR and in situ hybridization histochemistry to examine the expression of key genes in the hypothalamic appetite-regulating system, including Pomc and Npy as well as the genes expressing the receptors for leptin, ghrelin, and the melanocortins (79). They established that there were no differences in the expression of any of these genes between ovariectomized Kiss $1 r$ $\mathrm{KO}$ and ovariectomized control mice, suggesting peripheral sites of action of kisspeptin as potentially being a primary contributor to altered metabolism in the Kiss1r KO mouse. However, these sorts of assessments of mRNA levels do not preclude possible changes in neuronal activity and/or neurotransmitter release. They also do not fully address heterogeneity of the relevant neuronal populations and suggest that additional studies are needed to fully clarify a possible central role for kisspeptin signaling in energy metabolism. The following sections address the potential role of kisspeptin signaling in the major metabolic organs in the body, specifically the liver, muscle, fat, and pancreas.

\section{Liver-Derived Kisspeptin Participates in Islet Hormone Cross-Talk}

A long-standing question in pancreatic islet biology is how glucagon, produced in $\alpha$-cells in response to low glucose levels, influences insulin secretion from $\beta$-cells that occurs in states of hyperglycemia. These considerations have clinical relevance since patients with type 1 diabetes mellitus (T1DM) exhibit hyperglucagonemia (80). In addition, many patients with type 2 diabetes mellitus (T2DM) exhibit elevated glucagon levels and insufficient insulin secretion to control glucose levels $(81,82)$. High glucagon levels are also apparent in prediabetic patients, who exhibit impaired glucose tolerance, suggesting that impaired glucagon suppression may contribute to the development of T2DM $(83,84)$.

The glucagon receptor is expressed on hepatocytes, where its activation rapidly stimulates cyclic AMP (cAMP) production (85), activating the PKA-signaling cascade. The PKA regulatory complex consists of two catalytic subunits (C) and two regulatory subunits (R). The $\mathrm{C}$ subunits are sequestered by the $\mathrm{R}$ subunits in 
the absence of cAMP. Increases in CAMP result in the release of the $\mathrm{C}$ subunits which phosphorylate and activate CREB and increase the transcription of CREB-responsive genes. These include genes for the rate-limiting enzymes for gluconeogenesis, such as glucose6-phosphatase (G6pase) or phosphoenolpyruvate carboxykinase (Pepck) (86-88), providing the adaptive response of an increased hepatic glucose production in response to hypoglycemia.

Constitutive activation of liver PKA-dependent signaling stimulates gluconeogenesis, leading to hyperglycemia, which would be expected to stimulate insulin secretion from $\beta$-cells. However, experimentally, the opposite has been observed. In 2005, the McKnight laboratory developed a mouse model with liverspecific expression of a mutant PKA C subunit (tryptophan 196 to arginine, called $\mathrm{C} \alpha \mathrm{R}$ ) that exhibits impaired binding to the PKA $\mathrm{R}$ subunit and is thus less sequestered (inactive) in the absence of cAMP. The C $\alpha \mathrm{R}$ mice did not have an increased expression of the gluconeogenic enzymes G6pase or Pepck, but did have reduced hepatic glycogen levels and were found to have modest hyperglycemia, but this was not associated with higher insulin levels, but rather with a reduced insulin secretion (89). Similar results were observed by our group using a more robust model of constitutive hepatic PKA activation, one in which the PKA R subunit gene is completely disrupted by Cre/LoxP technology (L- $\Delta$ Prkarla mice). These mice have an increase in G6pase and Pepck gene expression in the liver causing fasting hyperglycemia and, notably, insufficient insulin secretion to correct glycemia during intraperitoneal glucose tolerance tests (13). These data suggest that an increased PKA signaling in the liver could be indirectly acting on pancreatic $\beta$-cells to suppress insulin secretion.

Evidence that a secreted factor was mediating this effect came from a bioassay in which plasma from L-Prkarla mice suppressed insulin secretion from wild-type (WT) mouse islets in vitro (13).

To identify the factor, we compared hepatic gene expression in the L- $\Delta$ Prkarla mouse with WT mice infused with glucose to achieve hyperglycemia equivalent to that in the L- $\Delta$ Prkarla mouse. Of note, glucose-infused WT mice exhibited a robust and significantly elevated insulin secretion in contrast to the L- $\Delta$ Prkar 1a counterparts. A liver gene expression array combined with bioinformatic analysis to identify genes for secreted proteins that were upregulated in the liver of L- $\Delta$ Prkarla mice surprisingly yielded a single candidate gene, Kiss1, that was significantly upregulated in L- $\Delta$ Prkarla liver (13). This result was confirmed by direct assessment of liver kisspeptin mRNA expression by quantitative PCR as well as kisspeptin protein levels by immunoblot.

Glucagon is secreted during fasting to participate in adaptive energy mobilization in the liver and fat. We demonstrated that Kiss 1 expression was increased in overnight fasted WT mice, but not in mice with a liver-specific deletion of the glucagon receptor gene. These results suggest that liver glucagon receptor activation can both stimulate insulin secretion by increasing blood glucose levels and inhibit insulin secretion by stimulating kisspeptin production.

To confirm the functional regulation of insulin secretion by the kisspeptin receptor, we used mice with selective ablation of the pancreatic Kiss1r gene (Panc-Kiss1R mouse) using the pancreas-specific PDX-1 CRE driver mouse and a Kiss1r floxed mouse that we developed (40). Acute treatment of control mice with kisspeptin preceding a glucose injection resulted in impaired glucose tolerance and attenuated insulin secretion, while PancKiss1R mice injected with kisspeptin before glucose injection had glucose tolerance and insulin secretion similar to vehicle-injected mice (13).

Attempts to assess a role for kisspeptin on insulin secretion have yielded conflicting results with some noting that kisspeptin stimulates glucose-stimulated insulin secretion (GSIS) $(90,91)$ and others reporting the opposite $(92,93)$. We noted a wide range of concentrations for kisspeptin used in these various studies, with kisspeptin concentrations in the $\mathrm{nM}$ range usually suppressing GSIS $(92,93)$ and $\mu \mathrm{M}$ kisspeptin concentrations usually stimulating GSIS $(90,91,94)$. To directly address this controversy, we tested different concentrations of kisspeptin on GSIS in islets from control and Panc-Kiss1R mice. We found that kisspeptin at $\mathrm{nM}$ concentrations suppressed GSIS from control islets but not from islets lacking the KISS1R. By contrast, kisspeptin at $\mu \mathrm{M}$ concentrations stimulated GSIS even in the absence of the KISS1R (Panc-Kiss1R islets). Based on these studies, it is clear that the suppression of GSIS by nanomolar concentrations of kisspeptin is mediated by the KISS1R. At supraphysiological levels, kisspeptin stimulates GSIS through a non-KISS1R-mediated pathway.

We assessed liver expression of kisspeptin in mouse models of obesity. Both high-fat diet (HFD) fed obese and genetic models of obesity ( $\mathrm{db} / \mathrm{db}$ and $\mathrm{Ob} / \mathrm{Ob}$ mice) had an increased liver kisspeptin expression as well as increased circulating plasma kisspeptin concentrations (13). To assess whether these results translated to humans, liver biopsies taken from patients diagnosed with T2DM were analyzed and exhibited a higher kisspeptin expression than liver tissue from non-diabetic subjects. This was associated with higher circulating kisspeptin levels in diabetic subjects than in non-diabetic subjects (13). These findings suggest that in T2DM, kisspeptin production is elevated in the liver and that this increased kisspeptin production is secondary to increased glucagon levels, and, indeed, treatment with a glucagon receptor antagonist in $\mathrm{db} / \mathrm{db}$ mice reduced liver kisspeptin production and improved glucose homeostasis (13).

Therefore, these data demonstrate the existence of a hepatopancreatic circuit in which glucagon, from the pancreas, stimulates hepatic expression of the genes regulating gluconeogenesis and kisspeptin. While the increased expression of Pepck and G6pase increases hepatic glucose output, increases blood glucose levels and stimulates insulin secretion, the increased secretion of kisspeptin serves to suppress insulin secretion (Figure 2). Kisspeptin could therefore be developed as a therapeutic in the treatment of some metabolic disease.

\section{Placenta Is a Major Source of Circulating Kisspeptin in Humans}

Our data suggest that the liver contributes to circulating levels of kisspeptin that in metabolically challenged states can increase 2- to 10-fold above basal (13); however, these levels are far lower than those secreted in women at the end of pregnancy by the placenta [elevated nearly 10,000-fold (32)]. This dramatic increase has been corroborated in a recent study in which urine kisspeptin levels were over 200-fold higher in third trimester pregnant women than in non-pregnant women (95). Kisspeptin 


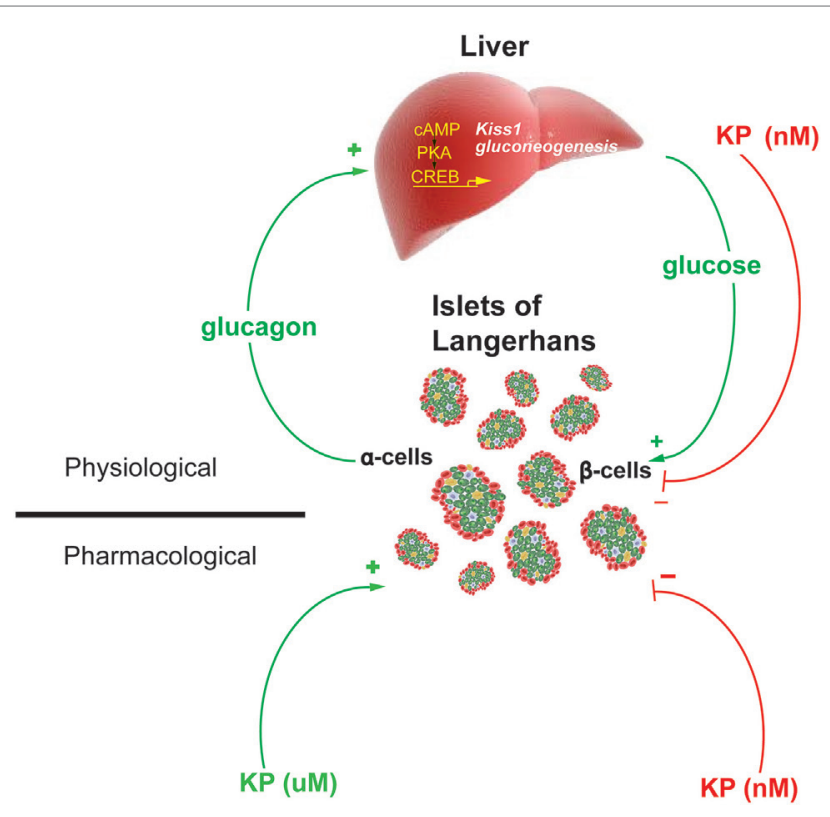

FIGURE 2 | Model of the proposed Hepato-Islet circuit. Glucagon secreted from the pancreatic $\alpha$-cell activates its receptor on the liver increasing PKA activity and gene expression of gluconeogenic genes and the Kiss1 gene. Increased glucose output from the liver increases blood glucose levels, increasing insulin secretion from the pancreatic $\beta$-cells. Increased kisspeptin secretion from the liver acts to suppress glucose-stimulated insulin secretion from the pancreatic $\beta$-cells. Pharmacologically delivered kisspeptin can stimulate ( $\mu \mathrm{M}$ levels) or inhibit (nM levels) GSIS. Figure adapted from Song et al. (13).

levels decline rapidly after delivery, supporting the placenta as the source (32). Human term placenta was analyzed for Kiss 1 mRNA by in situ hybridization and for kisspeptin by immunohistochemistry, and kisspeptin expression in the outer syncytiotrophoblasts was reported, ideally located for secreting kisspeptin into the maternal circulation (32). The authors noted that there are similarities between invasive placental cells and invasive cancer cells (32), and during the establishment of the maternal-fetal interface, it is important to limit the interaction between the trophoblasts and uterine cells. Perhaps, kisspeptin plays a role in this process, mirroring its originally defined role as a metastasis inhibitor (1). Therefore, the increase in the production of kisspeptin in syncytiotrophoblasts in the first trimester may also play a role in negatively regulating trophoblast invasion, and kisspeptin signaling might be required for implantation and placentation (96).

A metabolic role for placentally derived kisspeptin can also be envisioned. During normal human pregnancy, insulin resistance develops and peaks during late pregnancy [34-36 weeks of gestation (97)]. This may be an adaptive response to preserve a slight excess of energy substrates in the blood for use by the developing fetus. A number of hormones have been proposed to contribute to the development of insulin resistance, including human placental lactogen, human placental growth hormone, progesterone, cortisol, tumor necrosis factor $\alpha$, and leptin (97). One could envision two possible explanations for the high kisspeptin levels late in pregnancy. If kisspeptin is acting via the KISS1R, it would serve to tamp down increased insulin secretion to maintain a modest excess in the blood levels of energy substrates (glucose, free fatty acids). Intriguingly, insulin sensitivity recovers very quickly after delivery in parallel with decreasing kisspeptin levels $(32,97)$. One could also propose that the very high levels of kisspeptin circulating late in pregnancy could act via a kisspeptin receptor independent mechanism and serve to augment insulin secretion to compensate for the increased insulin resistance in late pregnancy.

Further investigation of placental kisspeptin will be difficult using many animal models. Very modest levels of placental kisspeptin expression have been reported in the rat, dog, and mouse (98-100). And while a gestational increase in kisspeptin expression was noted for mouse (99) and dog (98), circulating levels of kisspeptin are unlikely to reach the levels observed in humans and may not play the same role in these animal models as compared to humans.

\section{Fat May Also Be a Source of Circulating Kisspeptin}

The adipocyte could also be a source of circulating kisspeptin. Kiss 1 mRNA has been detected in rat adipose tissue $(30,31)$, and food restriction increased Kiss 1 mRNA in the fat of both male and female rats (30). T1DM but not T2DM was associated with roughly 100-fold higher Kiss1 mRNA levels in adipocytes compared to non-diabetic rats (24), suggesting that insulin plays a key role in the regulation of adipocyte Kiss1 expression. Interestingly, the large increase in Kiss 1 mRNA was not associated with increased kisspeptin protein levels in the adipocytes of T1DM rats, suggesting either increased secretion or reduced protein translation. By contrast, Kiss 1 mRNA was reduced in obese HFD fed and obese Zucker rats (30). The Wilkerson group also demonstrated a sex steroid regulation of adipocyte Kiss 1 expression. Estradiol stimulated expression in female adipocytes and testosterone stimulated expression in male adipocytes (30).

The adipocyte also expresses the KISS1R (101). Therefore, kisspeptins secreted by adipose tissue could either act as adipokines or as autocrine/paracrine regulators of adipocyte function. To explore kisspeptin's effects in fat, 3T3-L1 and primary rat hepatocytes were treated with Kp10 and lipid metabolism, glucose uptake and leptin and adiponectin secretion assessed (101). These studies demonstrated that Kp10 reduced adipogenesis in 3T3-L1 cells, likely as a result of a reduced expression of peroxisome proliferator-activated receptor gamma (PPAR- $\gamma$ ) and CCAAT/ enhancer binding protein beta (CEBP $\beta)$, transcription factors involved in stimulating adipogenesis. Kp10 increased lipolysis in 3T3-L1 cells and rat adipocytes by enhancing the expression of periliphin and hormone-sensitive lipase and decreased glucose uptake and lipogenesis. Kp10 also stimulated the secretion of leptin and decreased the secretion of adiponectin from rat adipocytes. While these studies suggest a role for kisspeptin in regulating adipocyte development and function, the effects were largely seen at near $\mu \mathrm{M}$ levels of $\mathrm{Kp} 10$, calling into question the physiological relevance of the findings. It is possible that local levels of paracrine/autocrine secretion of kisspeptin could reach these levels, or that the very high levels of kisspeptin observed during human pregnancy could achieve levels that functionally 
regulate fat, although this is unlikely to play a role in mouse or rat given the relatively modest levels of kisspeptin during gestation in these rodent models.

Human fat has also been demonstrated to express Kiss1 (31). In women, a positive correlation between Kiss 1 mRNA in visceral adipose tissue and body mass index (BMI) was reported (31). Exclusions for this study included women under 19 years old and those that were post-menopausal. Not excluded were subjects with diabetes. These findings agree with our observation that circulating kisspeptin levels are increased 2- to 4-fold in HFD fed and db/ $\mathrm{db}$ obese mice and nearly 10 -fold in humans with T2DM when compared to lean mice and non-diabetic humans, respectively (13). These findings are at odds with the rodent data showing a reduced Kiss 1 expression in obese rats (30), and they also appear to differ from studies showing decreased circulating kisspeptin levels in obese patients with BMIs above $35 \mathrm{~kg} / \mathrm{m}^{2}$ when compared to non-obese controls with BMIs below $25 \mathrm{~kg} / \mathrm{m}^{2}$ (102). However, the high BMI subjects in the Kolodziejskii study specifically excluded those with diabetes and they would not exhibit hyperglucagonemia and the resulting increased hepatic Kiss1 expression (102).
The contribution of fat to circulating levels of kisspeptin is unclear, making it difficult to discern whether kisspeptin from fat serves as an endocrine factor. A cell-specific $\mathrm{KO}$ of the kisspeptin gene from adipocytes would help address this question. These studies may ultimately demonstrate an exclusively paracrine/ autocrine role of kisspeptin in fat regulation.

\section{Other Potential Effects of Kisspeptin on Peripheral Metabolic Function}

Evidence for the muscle as a target or a source of kisspeptin is limited. While skeletal muscle has not been demonstrated to synthesize kisspeptin or express significant levels of the KISS1R, there is evidence that smooth and cardiac muscles are regulated by kisspeptin.

Kisspeptin receptor has been localized in cardiomyocytes as well as the smooth muscle cells of the intramyocardial blood vessels $(29,103)$, and kisspeptin has been demonstrated to induce inotropic actions on cardiac function with the effects confirmed to be mediated by the KISS1R (29). The relevance during normal

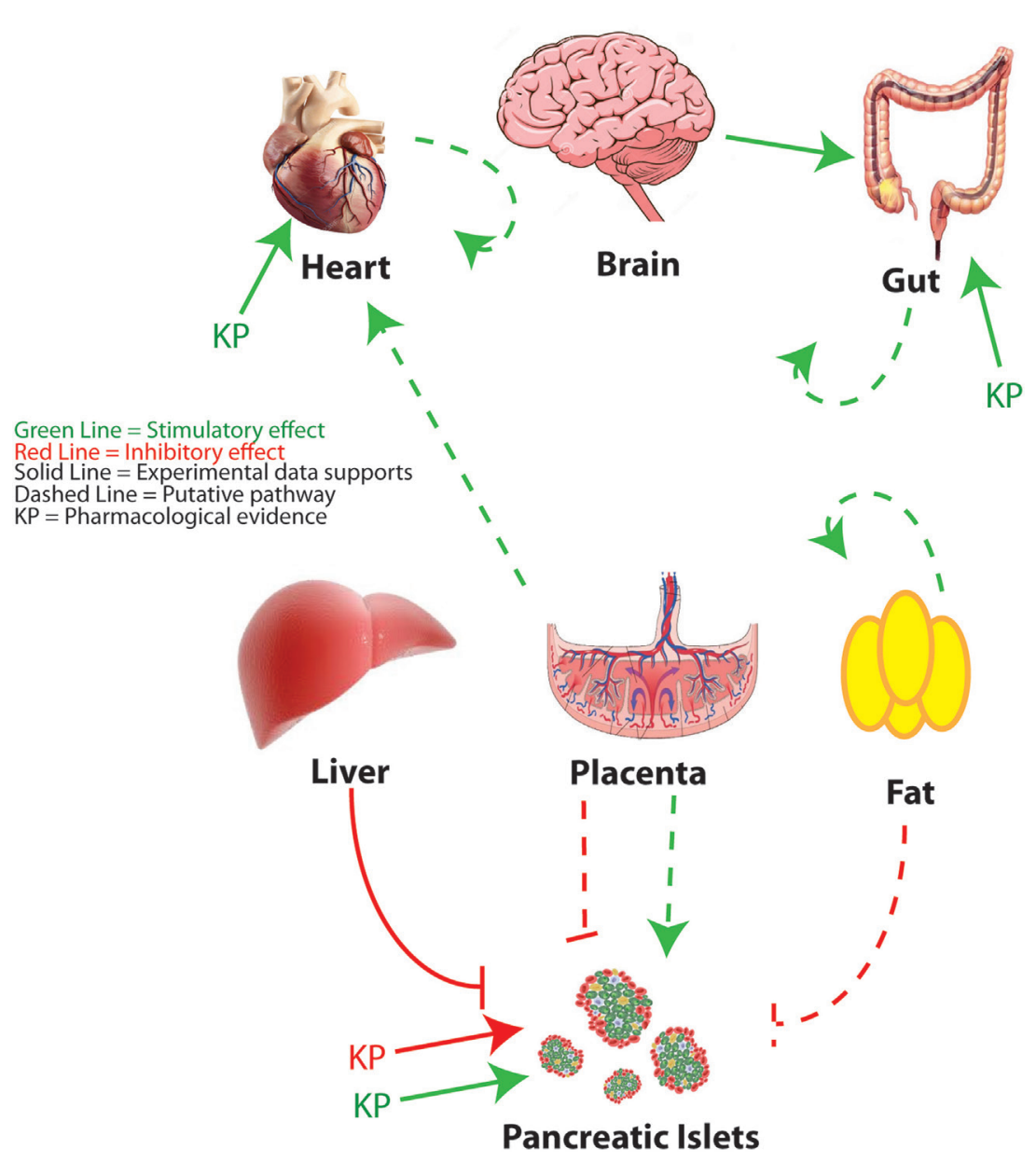

FIGURE 3 | Peripheral metabolic regulation by kisspeptin. An overview of kisspeptin regulatory pathways is discussed in this review. Red lines indicate putative suppressive effects. Green lines indicate putative stimulatory effects. Solid lines indicate that specific experimental evidence is provided to support the pathway. Dashed lines indicate a speculative pathway based on the available evidence. KP indicates targets for which pharmacological roles for kisspeptin have been proposed. Figure of brain adapted from Dreamstime.com. 
physiology is unclear, however, since no cardiac dysfunction is reported in either humans or mice lacking the KISS1R (29). It was proposed that the high levels of kisspeptin secreted from the placenta could play a role in the adaptive increase in cardiac output during pregnancy $(29,104)$. However, the local expression of kisspeptin-like immunoreactivity was noted in human, mouse, and rat vascular and endocardial endothelial cells and in human cardiomyocytes (29) and could also be a source of high kisspeptin levels. Local secretion of kisspeptin could be a mechanism for intracardial regulation of cardiac output. Interestingly, the level of kisspeptin immunoreactivity was significantly lower in the right atria of patients transplanted for ischemic heart disease when compared to controls. While these changes could be secondary to low oxygen levels, it could suggest a possible role for kisspeptin in maintaining proper blood flow to the heart during atherosclerotic arterial narrowing.

Regulation of gut motility also contributes to metabolic status. A recent report suggests that kisspeptin can stimulate gastrointestinal motility by both central and peripheral mechanisms (105). While ICV infusion of kisspeptin stimulated gastrointestinal motility and fecal output at low $\mathrm{nM}$ concentrations, kisspeptin also exerted direct effects on the contractility of the circular smooth muscle of the colon. However, the peripheral effects of kisspeptin in the colon were only apparent at $\mu \mathrm{M}$ concentrations and could indicate a non-KISS1R-mediated mechanism of action such as observed for the effects of high kisspeptin concentrations on the beta cell (13). Local secretion of kisspeptin could achieve $\mu \mathrm{M}$ levels and represent an endogenous regulatory mechanism in the gastrointestinal system. Alternatively, these studies may help define a therapeutic role for pharmacological kisspeptin.

Kisspeptin does not appear to directly impact energy metabolism of skeletal muscle, but the literature does indicate a potentially important role on cardiac function and gut motility. Leveraging conditional knockout mouse models of both kisspeptin and the KISS1R will be required to fully understand kisspeptin's role in regulating heart contractility and gut motility.

\section{REFERENCES}

1. Lee JH, Miele ME, Hicks DJ, Phillips KK, Trent JM, Weissman BE, et al. KiSS-1, a novel human malignant melanoma metastasis-suppressor gene. J Natl Cancer Inst (1996) 88:1731-7. doi:10.1093/jnci/88.23.1731

2. Ohtaki T, Shintani Y, Honda S, Matsumoto H, Hori A, Kanehashi K, et al. Metastasis suppressor gene KiSS-1 encodes peptide ligand of a G-proteincoupled receptor. Nature (2001) 411:613-7. doi:10.1038/35079135

3. Seminara SB, Messager S, Chatzidaki EE, Thresher RR, Acierno JS Jr, Shagoury JK, et al. The GPR54 gene as a regulator of puberty. $N$ Engl J Med (2003) 349:1614-27. doi:10.1056/NEJMoa035322

4. de Roux N, Genin E, Carel JC, Matsuda F, Chaussain JL, Milgrom E. Hypogonadotropic hypogonadism due to loss of function of the KiSS1derived peptide receptor GPR54. Proc Natl Acad Sci US A (2003) 100:10972-6. doi:10.1073/pnas.1834399100

5. Smith JT, Dungan HM, Stoll EA, Gottsch ML, Braun RE, Eacker SM, et al. Differential regulation of KiSS-1 mRNA expression by sex steroids in the brain of the male mouse. Endocrinology (2005) 146:2976-84. doi:10.1210/ en.2005-0488

6. Smith JT, Cunningham MJ, Rissman EF, Clifton DK, Steiner RA. Regulation of Kiss1 gene expression in the brain of the female mouse. Endocrinology (2005) 146:3686-92. doi:10.1210/en.2005-0323

\section{Summary and Conclusion}

As the study of kisspeptin enters its third decade, and new functions are attributed to the peptide, more animal and human studies are needed to understand its complex pleiotropic effects. The widespread expression of kisspeptin and its receptor indicates an ever-expanding array of roles in normal physiology, but also during the extreme physiological, developmental, and metabolic challenges of pregnancy or in pathophysiological states such as diabetes (Figure 3). In reviewing the literature, several challenges emerge. The first is that a spectrum of kisspeptin doses is being used, both in vivo and in vitro, and more attention needs to be paid to whether the effects of kisspeptin are physiological or pharmacological. This is not meant to disparage the latter since there is evidence that kisspeptins show a therapeutic potential in a variety of systems. A second challenge is trying to understand whether kisspeptins' effects are being mediated by the kisspeptin receptor and, if not, to determine those mechanisms of action not mediated by the cognate receptor. When possible, it is invaluable to validate the mechanism of action using the Kiss $1 \mathrm{R}$ KO mouse $(13,29)$. The development of novel mouse models, including mice with floxed alleles of both the kisspeptin (in development) and KISS1R $(40,106)$ genes and optogenetic tools to assess neurobiological circuitries $(50,51,107)$, will help define the sources of kisspeptin and the relevant sites of action. However, the development of additional animal and human models will be imperative to adequately study phenomenon not recapitulated in rodent models.

\section{AUTHOR CONTRIBUTIONS}

AW and $\mathrm{MH}$ jointly conceived of and wrote the manuscript.

\section{FUNDING}

The authors thank the National Institutes of Health (P30 DK079637, R01 DK101591, R01 HD 068777) for support of their research.

7. Dubois SL, Acosta-Martinez M, DeJoseph MR, Wolfe A, Radovick S, Boehm U, et al. Positive, but not negative feedback actions of estradiol in adult female mice require estrogen receptor alpha in kisspeptin neurons. Endocrinology (2015) 156:1111-20. doi:10.1210/en.2014-1851

8. Dror T, Franks J, Kauffman AS. Analysis of multiple positive feedback paradigms demonstrates a complete absence of LH surges and GnRH activation in mice lacking kisspeptin signaling. Biol Reprod (2013) 88:146. doi:10.1095/ biolreprod.113.108555

9. Manfredi-Lozano M, Roa J, Tena-Sempere M. Connecting metabolism and gonadal function: novel central neuropeptide pathways involved in the metabolic control of puberty and fertility. Front Neuroendocrinol (2017) 48:37-49. doi:10.1016/j.yfrne.2017.07.008

10. Manfredi-Lozano M, Roa J, Ruiz-Pino F, Piet R, Garcia-Galiano D, Pineda R, et al. Defining a novel leptin-melanocortin-kisspeptin pathway involved in the metabolic control of puberty. Mol Metab (2016) 5:844-57. doi:10.1016/j. molmet.2016.08.003

11. Cravo RM, Frazao R, Perello M, Osborne-Lawrence S, Williams KW, Zigman JM, et al. Leptin signaling in Kiss1 neurons arises after pubertal development. PLoS One (2013) 8:e58698. doi:10.1371/journal.pone.0058698

12. Katugampola H, King PJ, Chatterjee S, Meso M, Duncan AJ, Achermann JC, et al. Kisspeptin is a novel regulator of human fetal adrenocortical development and function: a finding with important implications for the human 
fetoplacental unit. J Clin Endocrinol Metab (2017) 102:3349-59. doi:10.1210/ jc. 2017-00763

13. Song WJ, Mondal P, Wolfe A, Alonso LC, Stamateris R, Ong BW, et al. Glucagon regulates hepatic kisspeptin to impair insulin secretion. Cell Metab (2014) 19:667-81. doi:10.1016/j.cmet.2014.03.005

14. Taylor J, Pampillo M, Bhattacharya M, Babwah AV. Kisspeptin/KISS1R signaling potentiates extravillous trophoblast adhesion to type-I collagen in a PKC- and ERK1/2-dependent manner. Mol Reprod Dev (2014) 81:42-54. doi: $10.1002 / \mathrm{mrd} .22279$

15. West A, Vojta PJ, Welch DR, Weissman BE. Chromosome localization and genomic structure of the KiSS-1 metastasis suppressor gene (KISS1). Genomics (1998) 54:145-8. doi:10.1006/geno.1998.5566

16. Kotani M, Detheux M, Vandenbogaerde A, Communi D, Vanderwinden JM, Le Poul E, et al. The metastasis suppressor gene KiSS-1 encodes kisspeptins, the natural ligands of the orphan G protein-coupled receptor GPR54. J Biol Chem (2001) 276:34631-6. doi:10.1074/jbc.M104847200

17. Tomikawa J, Uenoyama Y, Ozawa M, Fukanuma T, Takase K, Goto T, et al. Epigenetic regulation of Kiss1 gene expression mediating estrogenpositive feedback action in the mouse brain. Proc Natl Acad Sci U S A (2012) 109:E1294-301. doi:10.1073/pnas.1114245109

18. Castellano JM, Wright H, Ojeda SR, Lomniczi A. An alternative transcription start site yields estrogen-unresponsive Kiss1 mRNA transcripts in the hypothalamus of prepubertal female rats. Neuroendocrinology (2014) 99(2):94-107. doi:10.1159/000362280

19. Zhang X, Odom DT, Koo SH, Conkright MD, Canettieri G, Best J, et al. Genome-wide analysis of cAMP-response element binding protein occupancy, phosphorylation, and target gene activation in human tissues. Proc Natl Acad Sci U S A (2005) 102:4459-64. doi:10.1073/pnas.0501076102

20. Kim J, Semaan SJ, Clifton DK, Steiner RA, Dhamija S, Kauffman AS. Regulation of Kiss1 expression by sex steroids in the amygdala of the rat and mouse. Endocrinology (2011) 152:2020-30. doi:10.1210/en.2010-1498

21. Smith JT, Clifton DK, Steiner RA. Regulation of the neuroendocrine reproductive axis by kisspeptin-GPR54 signaling. Reproduction (2006) 131: 623-30. doi:10.1530/rep.1.00368

22. Smith JT, Popa SM, Clifton DK, Hoffman GE, Steiner RA. Kiss1 neurons in the forebrain as central processors for generating the preovulatory luteinizing hormone surge. J Neurosci (2006) 26:6687-94. doi:10.1523/JNEUROSCI. 1618-06.2006

23. Kauffman AS, Gottsch ML, Roa J, Byquist AC, Crown A, Clifton DK, et al. Sexual differentiation of Kiss 1 gene expression in the brain of the rat. Endocrinology (2007) 148:1774-83. doi:10.1210/en.2006-1540

24. Dudek M, Kolodziejski PA, Pruszynska-Oszmalek E, Sassek M, Ziarniak K, Nowak KW, et al. Effects of high-fat diet-induced obesity and diabetes on Kiss1 and GPR54 expression in the hypothalamic-pituitary-gonadal (HPG) axis and peripheral organs (fat, pancreas and liver) in male rats. Neuropeptides (2016) 56:41-9. doi:10.1016/j.npep.2016.01.005

25. Salehi S, Adeshina I, Chen H, Zirkin BR, Hussain MA, Wondisford F, et al. Developmental and endocrine regulation of kisspeptin expression in mouse Leydig cells. Endocrinology (2015) 156:1514-22. doi:10.1210/en. 2014-1606

26. Irfan S, Ehmcke J, Shahab M, Wistuba J, Schlatt S. Immunocytochemical localization of kisspeptin and kisspeptin receptor in the primate testis. J Med Primatol (2016) 45:105-11. doi:10.1111/jmp.12212

27. Castellano JM, Gaytan M, Roa J, Vigo E, Navarro VM, Bellido C, et al. Expression of KiSS-1 in rat ovary: putative local regulator of ovulation? Endocrinology (2006) 147:4852-62. doi:10.1210/en.2006-0117

28. Yamasaki M, Kuwahara A, Iwasa T, Yamamoto Y, Taniguchi Y, Yano Y, et al. Development-related changes in the expression of the ovarian Kiss1 and Kisslr genes and their sensitivity to human chorionic gonadotropin in prepubertal female rats. J Reprod Dev (2017) 63:409-14. doi:10.1262/jrd. 2016-179

29. Maguire JJ, Kirby HR, Mead EJ, Kuc RE, d'Anglemont de Tassigny X, Colledge $\mathrm{WH}$, et al. Inotropic action of the puberty hormone kisspeptin in rat, mouse and human: cardiovascular distribution and characteristics of the kisspeptin receptor. PLoS One (2011) 6:e27601. doi:10.1371/journal. pone. 0027601

30. Brown RE, Imran SA, Ur E, Wilkinson M. KiSS-1 mRNA in adipose tissue is regulated by sex hormones and food intake. Mol Cell Endocrinol (2008) 281:64-72. doi:10.1016/j.mce.2007.10.011
31. Cockwell H, Wilkinson DA, Bouzayen R, Imran SA, Brown R, Wilkinson M. KISS1 expression in human female adipose tissue. Arch Gynecol Obstet (2013) 287:143-7. doi:10.1007/s00404-012-2514-0

32. Horikoshi Y, Matsumoto H, Takatsu Y, Ohtaki T, Kitada C, Usuki S, et al. Dramatic elevation of plasma metastin concentrations in human pregnancy: metastin as a novel placenta-derived hormone in humans. J Clin Endocrinol Metab (2003) 88:914-9. doi:10.1210/jc.2002-021235

33. Colledge WH. GPR54 and kisspeptins. Results Probl Cell Differ (2008) 46:117-43. doi:10.1007/400_2007_050

34. Lee DK, Nguyen T, O'Neill GP, Cheng R, Liu Y, Howard AD, et al. Discovery of a receptor related to the galanin receptors. FEBS Lett (1999) 446:103-7. doi:10.1016/S0014-5793(99)00009-5

35. Liu X, Lee K, Herbison AE. Kisspeptin excites gonadotropin-releasing hormone neurons through a phospholipase $\mathrm{C} /$ calcium-dependent pathway regulating multiple ion channels. Endocrinology (2008) 149:4605-14. doi:10.1210/ en.2008-0321

36. Bianco SD, Kaiser UB. Molecular biology of the kisspeptin receptor: signaling, function, and mutations. Adv Exp Med Biol (2013) 784:133-58. doi:10.1007/978-1-4614-6199-9_7

37. Ahow M, Min L, Pampillo M, Nash C, Wen J, Soltis K, et al. KISS1R signals independently of Galphaq/11 and triggers LH secretion via the beta-arrestin pathway in the male mouse. Endocrinology (2014) 155:4433-46. doi:10.1210/ en.2014-1304

38. Babwah AV, Navarro VM, Ahow M, Pampillo M, Nash C, Fayazi M, et al. GnRH neuron-specific ablation of Galphaq/11 results in only partial inactivation of the neuroendocrine-reproductive axis in both male and female mice: in vivo evidence for Kiss1r-coupled Galphaq/11-independent GnRH secretion. J Neurosci (2015) 35:12903-16. doi:10.1523/JNEUROSCI.0041-15.2015

39. Lehman MN, Hileman SM, Goodman RL. Neuroanatomy of the kisspeptin signaling system in mammals: comparative and developmental aspects. $A d v$ Exp Med Biol (2013) 784:27-62. doi:10.1007/978-1-4614-6199-9_3

40. Novaira HJ, Sonko ML, Hoffman G, Koo Y, Ko C, Wolfe A, et al. Disrupted kisspeptin signaling in $\mathrm{GnRH}$ neurons leads to reproductive abnormalities and HH. Mol Endocrinol (2014) 28(2):225-38. doi:10.1210/me.2013-1319

41. Gutierrez-Pascual E, Martinez-Fuentes AJ, Pinilla L, Tena-Sempere M, Malagon MM, Castano JP. Direct pituitary effects of kisspeptin: activation of gonadotrophs and somatotrophs and stimulation of luteinising hormone and growth hormone secretion. J Neuroendocrinol (2007) 19:521-30. doi:10.1111/j.1365-2826.2007.01558.x

42. Richard N, Galmiche G, Corvaisier S, Caraty A, Kottler ML. KiSS-1 and GPR54 genes are co-expressed in rat gonadotrophs and differentially regulated in vivo by oestradiol and gonadotrophin-releasing hormone. J Neuroendocrinol (2008) 20:381-93. doi:10.1111/j.1365-2826.2008.01653.x

43. Muir AI, Chamberlain L, Elshourbagy NA, Michalovich D, Moore DJ, Calamari A, et al. AXOR12, a novel human G protein-coupled receptor, activated by the peptide KiSS-1. J Biol Chem (2001) 276:28969-75. doi:10.1074/ jbc.M102743200

44. Simonin F, Schmitt M, Laulin JP, Laboureyras E, Jhamandas JH, MacTavish D, et al. RF9, a potent and selective neuropeptide FF receptor antagonist, prevents opioid-induced tolerance associated with hyperalgesia. Proc Natl Acad Sci U S A (2006) 103:466-71. doi:10.1073/pnas.0502090103

45. Liu X, Herbison AE. RF9 excitation of GnRH neurons is dependent upon Kiss1r in the adult male and female mouse. Endocrinology (2014) 155: 4915-24. doi:10.1210/en.2014-1517

46. Min L, Leon S, Li H, Pinilla L, Carroll RS, Tena-Sempere M, et al. RF9 acts as a KISS1R agonist in vivo and in vitro. Endocrinology (2015) 156:4639-48. doi:10.1210/en.2015-1635

47. Lapatto R, Pallais JC, Zhang D, Chan YM, Mahan A, Cerrato F, et al. Kiss1-/mice exhibit more variable hypogonadism than Gpr54-/- mice. Endocrinology (2007) 148:4927-36. doi:10.1210/en.2007-0078

48. Lehman MN, Merkley CM, Coolen LM, Goodman RL. Anatomy of the kisspeptin neural network in mammals. Brain Res (2010) 1364:90-102. doi:10.1016/j.brainres.2010.09.020

49. Smith JT, Acohido BV, Clifton DK, Steiner RA. KiSS-1 neurons are direct targets for leptin in the ob/ob mouse. J Neuroendocrinol (2006) 18:298-303. doi:10.1111/j.1365-2826.2006.01417.x

50. Clarkson J, Han SY, Piet R, McLennan T, Kane GM, Ng J, et al. Definition of the hypothalamic GnRH pulse generator in mice. Proc Natl Acad Sci U S A (2017) 114(47):E10216-23. doi:10.1073/pnas.1713897114 
51. Han SY, McLennan T, Czieselsky K, Herbison AE. Selective optogenetic activation of arcuate kisspeptin neurons generates pulsatile luteinizing hormone secretion. Proc Natl Acad Sci U S A (2015) 112:13109-14. doi:10.1073/ pnas. 1512243112

52. Beale KE, Kinsey-Jones JS, Gardiner JV, Harrison EK, Thompson EL, Hu MH, et al. The physiological role of arcuate kisspeptin neurons in the control of reproductive function in female rats. Endocrinology (2014) 155:1091-8. doi:10.1210/en.2013-1544

53. Wakabayashi Y, Yamamura T, Sakamoto K, Mori Y, Okamura H. Electrophysiological and morphological evidence for synchronized GnRH pulse generator activity among kisspeptin/neurokinin B/dynorphin A (KNDy) neurons in goats. J Reprod Dev (2013) 59:40-8. doi:10.1262/jrd.2012-136

54. Navarro VM, Gottsch ML, Chavkin C, Okamura H, Clifton DK, Steiner RA. Regulation of gonadotropin-releasing hormone secretion by kisspeptin/ dynorphin/neurokinin B neurons in the arcuate nucleus of the mouse. J Neurosci (2009) 29:11859-66. doi:10.1523/JNEUROSCI.1569-09.2009

55. Comninos AN, Jayasena CN, Dhillo WS. The relationship between gut and adipose hormones, and reproduction. Hum Reprod Update (2014) 20:153-74. doi:10.1093/humupd/dmt033

56. Castellano JM, Bentsen AH, Mikkelsen JD, Tena-Sempere M. Kisspeptins: bridging energy homeostasis and reproduction. Brain Res (2010) 1364: 129-38. doi:10.1016/j.brainres.2010.08.057

57. Backholer K, Smith JT, Rao A, Pereira A, Iqbal J, Ogawa S, et al. Kisspeptin cells in the ewe brain respond to leptin and communicate with neuropeptide Y and proopiomelanocortin cells. Endocrinology (2010) 151:2233-43. doi:10.1210/en.2009-1190

58. Luque RM, Kineman RD, Tena-Sempere M. Regulation of hypothalamic expression of KiSS-1 and GPR54 genes by metabolic factors: analyses using mouse models and a cell line. Endocrinology (2007) 148:4601-11. doi:10.1210/ en.2007-0500

59. Castellano JM, Navarro VM, Fernandez-Fernandez R, Nogueiras R, Tovar S, Roa J, et al. Changes in hypothalamic KiSS-1 system and restoration of pubertal activation of the reproductive axis by kisspeptin in undernutrition. Endocrinology (2005) 146:3917-25. doi:10.1210/en.2005-0337

60. Kalamatianos T, Grimshaw SE, Poorun R, Hahn JD, Coen CW. Fasting reduces KiSS-1 expression in the anteroventral periventricular nucleus (AVPV): effects of fasting on the expression of KiSS-1 and neuropeptide $\mathrm{Y}$ in the AVPV or arcuate nucleus of female rats. J Neuroendocrinol (2008) 20:1089-97. doi:10.1111/j.1365-2826.2008.01757.x

61. Quennell JH, Howell CS, Roa J, Augustine RA, Grattan DR, Anderson GM. Leptin deficiency and diet-induced obesity reduce hypothalamic kisspeptin expression in mice. Endocrinology (2011) 152:1541-50. doi:10.1210/en. 2010-1100

62. Donato J Jr, Cravo RM, Frazao R, Gautron L, Scott MM, Lachey J, et al. Leptin's effect on puberty in mice is relayed by the ventral premammillary nucleus and does not require signaling in Kiss1 neurons. J Clin Invest (2011) 121:355-68. doi:10.1172/JCI45106

63. Mounzih K, Lu R, Chehab FF. Leptin treatment rescues the sterility of genetically obese ob/ob males. Endocrinology (1997) 138:1190-3. doi:10.1210/ endo.138.3.5024

64. Forbes S, Li XF, Kinsey-Jones J, O’Byrne K. Effects of ghrelin on kisspeptin mRNA expression in the hypothalamic medial preoptic area and pulsatile luteinising hormone secretion in the female rat. Neurosci Lett (2009) 460:143-7. doi:10.1016/j.neulet.2009.05.060

65. Frazao R, Dungan Lemko HM, da Silva RP, Ratra DV, Lee CE, Williams KW, et al. Estradiol modulates Kiss1 neuronal response to ghrelin. Am J Physiol Endocrinol Metab (2014) 306:E606-14. doi:10.1152/ajpendo.00211.2013

66. Louis GW, Greenwald-Yarnell M, Phillips R, Coolen LM, Lehman MN, Myers MG Jr. Molecular mapping of the neural pathways linking leptin to the neuroendocrine reproductive axis. Endocrinology (2011) 152:2302-10. doi:10.1210/en.2011-0096

67. Yeo SH. Neuronal circuits in the hypothalamus controlling gonadotrophinreleasing hormone release: the neuroanatomical projections of kisspeptin neurons. Exp Physiol (2013) 98:1544-9. doi:10.1113/expphysiol.2013. 071944

68. Yip SH, Boehm U, Herbison AE, Campbell RE. Conditional viral tract tracing delineates the projections of the distinct kisspeptin neuron populations to gonadotropin-releasing hormone $(\mathrm{GnRH})$ neurons in the mouse. Endocrinology (2015) 156:2582-94. doi:10.1210/en.2015-1131
69. Roa J, Garcia-Galiano D, Varela L, Sanchez-Garrido MA, Pineda R, Castellano JM, et al. The mammalian target of rapamycin as novel central regulator of puberty onset via modulation of hypothalamic Kiss1 system. Endocrinology (2009) 150:5016-26. doi:10.1210/en.2009-0096

70. Matsuzaki T, Iwasa T, Kinouchi R, Yoshida S, Murakami M, Gereltsetseg G, et al. Fasting reduces the kiss1 mRNA levels in the caudal hypothalamus of gonadally intact adult female rats. Endocr J (2011) 58:1003-12. doi:10.1507/ endocrj.K11E-131

71. Tolson KP, Garcia C, Yen S, Simonds S, Stefanidis A, Lawrence A, et al. Impaired kisspeptin signaling decreases metabolism and promotes glucose intolerance and obesity. J Clin Invest (2014) 124(7):3075-9. doi:10.1172/ JCI71075

72. Ohlsson C, Hellberg N, Parini P, Vidal O, Bohlooly-Y M, Rudling M, et al. Obesity and disturbed lipoprotein profile in estrogen receptor-alpha-deficient male mice. Biochem Biophys Res Commun (2000) 278:640-5. doi:10.1006/ bbrc. 2000.3827

73. Heine PA, Taylor JA, Iwamoto GA, Lubahn DB, Cooke PS. Increased adipose tissue in male and female estrogen receptor-alpha knockout mice. Proc Natl Acad Sci U S A (2000) 97:12729-34. doi:10.1073/pnas.97.23.12729

74. Butera PC. Estradiol and the control of food intake. Physiol Behav (2010) 99:175-80. doi:10.1016/j.physbeh.2009.06.010

75. Even PC, Nadkarni NA. Indirect calorimetry in laboratory mice and rats: principles, practical considerations, interpretation and perspectives. Am J Physiol Regul Integr Comp Physiol (2012) 303:R459-76. doi:10.1152/ajpregu. 00137.2012

76. Tolson KP, Garcia C, Delgado I, Marooki N, Kauffman AS. Metabolism and energy expenditure, but not feeding or glucose tolerance, are impaired in young Kiss1r KO female mice. Endocrinology (2016) 157:4192-9. doi:10.1210/en.2016-1501

77. Fu LY, van den Pol AN. Kisspeptin directly excites anorexigenic proopiomelanocortin neurons but inhibits orexigenic neuropeptide $\mathrm{Y}$ cells by an indirect synaptic mechanism. J Neurosci (2010) 30:10205-19. doi:10.1523/ JNEUROSCI.2098-10.2010

78. Nestor CC, Qiu J, Padilla SL, Zhang C, Bosch MA, Fan W, et al. Optogenetic stimulation of arcuate nucleus kiss 1 neurons reveals a steroid-dependent glutamatergic input to POMC and AgRP neurons in male mice. Mol Endocrinol (2016) 30:630-44. doi:10.1210/me.2016-1026

79. De Bond JP, Tolson KP, Nasamran C, Kauffman AS, Smith JT. Unaltered hypothalamic metabolic gene expression in Kiss1r knockout mice despite obesity and reduced energy expenditure. J Neuroendocrinol (2016) 28. doi:10.1111/ jne. 12430

80. Reaven GM, Chen YD, Golay A, Swislocki AL, Jaspan JB. Documentation of hyperglucagonemia throughout the day in nonobese and obese patients with noninsulin-dependent diabetes mellitus. J Clin Endocrinol Metab (1987) 64:106-10. doi:10.1210/jcem-64-1-106

81. Muller WA, Faloona GR, Unger RH. Hyperglucagonemia in diabetic ketoacidosis. Its prevalence and significance. Am J Med (1973) 54:52-7. doi:10.1016/ 0002-9343(73)90083-1

82. Baron AD, Schaeffer L, Shragg P, Kolterman OG. Role of hyperglucagonemia in maintenance of increased rates of hepatic glucose output in type II diabetics. Diabetes (1987) 36:274-83. doi:10.2337/diab.36.3.274

83. Mitrakou A, Kelley D, Mokan M, Veneman T, Pangburn T, Reilly J, et al. Role of reduced suppression of glucose production and diminished early insulin release in impaired glucose tolerance. N Engl J Med (1992) 326:22-9. doi:10.1056/NEJM199201023260104

84. Ahren B, Larsson H. Impaired glucose tolerance (IGT) is associated with reduced insulin-induced suppression of glucagon concentrations. Diabetologia (2001) 44:1998-2003. doi:10.1007/s001250100003

85. Dentin R, Liu Y, Koo SH, Hedrick S, Vargas T, Heredia J, et al. Insulin modulates gluconeogenesis by inhibition of the coactivator TORC2. Nature (2007) 449:366-9. doi:10.1038/nature06128

86. Herzig S, Long F, Jhala US, Hedrick S, Quinn R, Bauer A, et al. CREB regulates hepatic gluconeogenesis through the coactivator PGC-1. Nature (2001) 413:179-83. doi:10.1038/35093131

87. Montminy MR, Gonzalez GA, Yamamoto KK. Regulation of cAMPinducible genes by CREB. Trends Neurosci (1990) 13:184-8. doi:10.1016/ 0166-2236(90)90045-C

88. Brindle PK, Montminy MR. The CREB family of transcription activators. Curr Opin Genet Dev (1992) 2:199-204. doi:10.1016/S0959-437X(05)80274-6 
89. Niswender CM, Willis BS, Wallen A, Sweet IR, Jetton TL, Thompson BR, et al. Cre recombinase-dependent expression of a constitutively active mutant allele of the catalytic subunit of protein kinase A. Genesis (2005) 43:109-19. doi:10.1002/gene.20159

90. Hauge-Evans AC, Richardson CC, Milne HM, Christie MR, Persaud SJ, Jones PM. A role for kisspeptin in islet function. Diabetologia (2006) 49: 2131-5. doi:10.1007/s00125-006-0343-Z

91. Schwetz TA, Reissaus CA, Piston DW. Differential stimulation of insulin secretion by GLP-1 and kisspeptin-10. PLoS One (2014) 9:e113020. doi:10.1371/ journal.pone.0113020

92. Silvestre RA, Egido EM, Hernandez R, Marco J. Kisspeptin-13 inhibits insulin secretion without affecting glucagon or somatostatin release: study in the perfused rat pancreas. J Endocrinol (2008) 196:283-90. doi:10.1677/ JOE-07-0454

93. Vikman J, Ahren B. Inhibitory effect of kisspeptins on insulin secretion from isolated mouse islets. Diabetes Obes Metab (2009) 11(Suppl 4):197-201. doi:10.1111/j.1463-1326.2009.01116.x

94. Bowe JE, King AJ, Kinsey-Jones JS, Foot VL, Li XF, O’Byrne KT, et al. Kisspeptin stimulation of insulin secretion: mechanisms of action in mouse islets and rats. Diabetologia (2009) 52:855-62. doi:10.1007/s00125-009-1283-1

95. Jayasena CN, Comninos AN, Narayanaswamy S, Abbara A, Nijher GM, Cheema $\mathrm{M}$, et al. The identification of elevated urinary kisspeptinimmunoreactivity during pregnancy. Ann Clin Biochem (2015) 52:395-8. doi:10.1177/0004563214551612

96. Babwah AV. Uterine and placental KISS1 regulate pregnancy: what we know and the challenges that lie ahead. Reproduction (2015) 150:R121-8. doi:10.1530/REP-15-0252

97. Ryan EA. Hormones and insulin resistance during pregnancy. Lancet (2003) 362:1777-8. doi:10.1016/S0140-6736(03)14942-2

98. Schafer-Somi S, Ay SS, Kaya D, Sozmen M, Beceriklisoy HB, Agaoglu AR, et al. Kisspeptin-10 and the G protein-coupled receptor 54 are differentially expressed in the canine pregnant uterus and trophoblast cells. Reprod Domest Anim (2017) 52(Suppl 2):123-9. doi:10.1111/rda.12818

99. Herreboudt AM, Kyle VR, Lawrence J, Doran J, Colledge WH. Kiss1 mutant placentas show normal structure and function in the mouse. Placenta (2015) 36:52-8. doi:10.1016/j.placenta.2014.10.016

100. Oride A, Kanasaki H, Mijiddorj T, Sukhbaatar U, Ishihara T, Kyo S. Regulation of kisspeptin and gonadotropin-releasing hormone expression in rat placenta: study using primary cultures of rat placental cells. Reprod Biol Endocrinol (2015) 13:90. doi:10.1186/s12958-015-0083-3

101. Pruszynska-Oszmalek E, Kolodziejski PA, Sassek M, Sliwowska JH. Kisspeptin-10 inhibits proliferation and regulates lipolysis and lipogenesis processes in 3T3-L1 cells and isolated rat adipocytes. Endocrine (2017) 56:54-64.doi:10.1007/s12020-017-1248-y

102. Kolodziejskii PA, Pruszynska-Oszmalek E, Korek E, Sassek M, Szczepankiewicz D, Kaczmarek P, et al. Serum levels of spexin and kisspeptin negatively correlate with obesity and insulin resistance in women. Physiol Res (2017) 67(1):45-56.

103. Zhang Y, Hou Y, Wang X, Ping J, Ma Z, Suo C, et al. The effects of kisspeptin-10 on serum metabolism and myocardium in rats. PLoS One (2017) 12:e0179164. doi:10.1371/journal.pone.0179164

104. Katz R, Karliner JS, Resnik R. Effects of a natural volume overload state (pregnancy) on left ventricular performance in normal human subjects. Circulation (1978) 58:434-41. doi:10.1161/01.CIR.58.3.434

105. Jiang J, Jin W, Peng Y, He Z, Wei L, Li S, et al. In vivo and vitro characterization of the effects of kisspeptin-13, endogenous ligands for GPR54, on mouse gastrointestinal motility. Eur J Pharmacol (2017) 794:216-23. doi:10.1016/j. ejphar.2016.11.041

106. Kirilov M, Clarkson J, Liu X, Roa J, Campos P, Porteous R, et al. Dependence of fertility on kisspeptin-Gpr54 signaling at the GnRH neuron. Nat Commun (2013) 4:2492. doi:10.1038/ncomms3492

107. Qiu J, Nestor CC, Zhang C, Padilla SL, Palmiter RD, Kelly MJ, et al. High-frequency stimulation-induced peptide release synchronizes arcuate kisspeptin neurons and excites GnRH neurons. Elife (2016) 5:e16246. doi:10.7554/eLife.16246

Conflict of Interest Statement: The authors declare that the research was conducted in the absence of any commercial or financial relationships that could be construed as a potential conflict of interest.

Copyright (c) 2018 Wolfe and Hussain. This is an open-access article distributed under the terms of the Creative Commons Attribution License (CC BY). The use, distribution or reproduction in other forums is permitted, provided the original author(s) and the copyright owner are credited and that the original publication in this journal is cited in accordance with accepted academic practice. No use, distribution or reproduction is permitted which does not comply with these terms. 